\title{
Household structure, migration trends and residential preferences in inner- city León, Spain: unpacking the demographies of reurbanization
}

\begin{abstract}
This paper looks at the changing demographic features of the Spanish city of León, with the aim of exploring the manner in which its urban fabric has underwent processes of reurbanization: a dynamic whereby the inner city is becoming more attractive for a wide variety of household types and social groups. The paper draws on socio-demographic analyses of municipal census data, as well as a customized questionnaire survey of local residents. Empirical evidence is provided both for the city as a whole and two inner-city districts: Casco Antiguo and El Ejido. Among other findings, the paper argues that, although the contiguous built-up area of the city is clearly losing its inhabitants through processes of out-migration and ageing, there are a series of small-scale migration flows that are increasing the concentration of "non-traditional" households in the city centre and the areas around it. This is accompanied by an increasing trend towards "city-mindedness" as a residential choice and housing preference among both in-migrants and the long-standing residential population. In its entirety, the surveyed evidence points to the emergence of a spatially fragile and fragmented reurbanisation process.
\end{abstract}

\section{INTRODUCTION}

The last ten years have seen an increasing number of claims, within academic and policy circles alike, that many Western European and Northern American cities are undergoing processes of "reurbanization" (see, for instance, Buzar et al. 2007a; 2007b; Haase et al. 2006, Lever 1993). This dynamic, which is purported to be qualitatively different from the directionally similar, yet theoretically distinct trends of urban regeneration and gentrification, is generally seen as a broad process of repopulating and "residentializing" formerly declining (in terms of functions and population) inner urban areas with a wide variety of social groups. Unlike gentrification, reurbanization is understood to involve a wide variety of social classes and migration flows, while being driven by a general residential preference towards urban life (Buzar et al. 2007a). However, its causes, extent and nature remain unclear, partly as a result of the lack of context-sensitive studies of cities within lower tiers of the urban hierarchy in countries outside the Anglo-American realm. Not only is little known about the spatial variation of population change within the internal fabric of such cities, but there is also a paucity of data about the effects of reurbanization on residential mobility and housing preferences.

In response to such challenges, this paper examines the extent to which socio-demographic signs of reurbanization are present in León, a town of 136,000 inhabitants in the northern Spanish province of Castile and León (see Figure 1). Having faced population loss from the urban core, León's inner city has recently shown signs of recovery linked to new processes of in-migration and residential change (Fernández, 2007). Cities of this size have rarely been studied within the Spanish (and, more generally, developed-world) context, although much has been written about the "comeback" of larger Spanish metropolitan centres in terms of their rising attractiveness for a variety of population groups, ongoing cultural and residential 
rehabilitation efforts, as well as the regeneration of derelict industrial areas (Dura-Guimera, 2003; Luna-Garcia, 2003; Muñoz, 2003; Vicario, 2003). Such changes are being increasingly documented and discussed not only in the national context, but also within a rapidly growing international debate (see Dura-Guimera, 2003 or Luna-Garcia, 2003 in the special issue of Cities, vol. 20, no. 6).

The paper uses a variety of methods to explore the extent to which the inner urban fabric of León exhibits signs of reurbanization, which would imply that its inner-city areas are becoming more attractive for a variety of household types and residential groups (in line with the definition of the term developed in Buzar et al., 2007b). More specifically, we seek to investigate whether:

1. there is a general context of urban demographic decline in the city, by examining how population trends at the level of the entire city have changed over the past two decades;

2. the inner city exhibits an increased concentration relocation of "non-traditional" households, with the aid of an analysis of migration trends and household structures in some of its constituent neighbourhoods;

3. there are any specific residential preferences that underpin such population movements.

Being aware of the problem of taking confined definitions of urban cores (e.g. Bromley et al., 2005) our analysis operates at two levels: first, two large structural units within the León urban area, one of which contains the inner city; and second, two smaller districts within the inner city itself, where we have undertaken more detailed investigations. In addition to various strands of census and civil registry data ${ }^{1}$, we have also relied on a specially-designed questionnaire survey that was implemented in the two districts. Adding to the survey were eight semi-structured interviews with local residents, as well as a number of public policy officials and civil society representatives. The analyses of these sources of information form the three main sections of the paper, corresponding to the three research questions above. They are preceded by a broad-level review of social and economic developments at the national and regional scales.

\section{REURBANIZATION, GENTRIFICATION, AND THE SECOND DEMOGRAPHIC TRANSITION}

The concept of "reurbanization" has been present in the relevant academic and policy literatures for over 30 years (e.g. van den Berg et al., 1982; Lever, 1993; Buzar et al., 2007a; 2007b). It is generally taken to comprise three sets of dynamics: first, the demographic rejuvenation of inner-city areas in quantitative terms, including the relative growth of population and household numbers, as well as the diversification of household structures (Buzar et al., 2007a); second, the qualitative aspects of inner-city "revitalization," which involve increased residential attractiveness (Seo, 2002); and third, a long-term stabilization of the residential population, social mix and housing functions of the inner city (Cheshire, 2006, p. 1240; Burton, 2000; 2003). As such, it is closely linked to the idea of "urban resurgence" which has been the subject of a number of special issues (e.g. Urban Studies vol. 43, no. 8), international studies comprising entire continents (Turok and Mykhnenko, 2006) as well as comparative analyses of urban change across different countries (Markusen and Schrock, 
2006; Turok and Mykhnenko, 2007). Aside from resurgence, some scholars have also talked about an "urban renaissance" (Helbrecht, 1996) which is associated with a more general "comeback" of cities (Storper and Manville, 2006, p. 1247). In broader terms, these concepts have been defined "against a context of previous decline," although they have been distinguished "from simple growth as such" (Cheshire, 2006, p. 1232).

The fact that reurbanization's vision of "urban liveability, mixed-use and sustainable community development" displays a "language ... familiar to many gentrification scholars" (Colomb, 2007, p. 13) has resulted in the concept being subjected to a series of theoretical critiques, whose proponents fear that the term has been co-opted by urban developers as a discursive method of camouflaging the adverse social impacts of gentrification. Some of the key contributions within this vein of work argue that the demographic aspects of reurbanization are being quietly brought into the urban revitalization debate in order to remove "class" from mainstream conceptualizations of gentrification (Van Criekingen, 2007; Slater 2008) or urban studies more generally (Bürkner, 2008). They suggest that gentrification can be "stretched out" to comprise many of the constituent dynamics of reurbanization without compromising the original, class-based meaning of the term.

We do not subscribe to this view, as it is our belief that, according to their most commonly accepted definitions at least (e.g. Smith and Butler, 2007; Buzar et al., 2007a), the concepts of reurbanization and gentrification set out to describe different sets of processes. In our understanding, reurbanization refers to a much wider range of dynamics compared to gentrification, since its main purpose is to capture the rising overall "liveability" and "survivability" of compact inner-city areas for a wider range of social classes and demographic groups (Jenks et al., 1996; Williams et al., 2000). In conceptual terms, gentrification, with its focus on the politics of displacement and selective urban upgrading (e.g. Slater, 2006), cannot be equated with the broader, multi-directional process of reurbanization, which takes place over the entire inner city and is principally indicated by increasing in-migration and/or decreasing out-migration rates after a long phase of decline (e.g. Buzar et al., 2007b; Lambert and Boddy, 2002). Moreover, reurbanization entails a wide variety of migration flows into the entire inner city, often involving marginalized social groups such as international migrants and working-class families with children that cannot be considered "gentrifiers" under the conventional understanding of the term. In this context, one of the decisive driving forces of reurbanization is the often neglected interplay of housing markets, urban development and population change (Myers, 1990).

For such reasons, the empirical research that led to the publication of this paper was not geared towards detecting processes of gentrification (for example, questions about income were not part of the survey of local residents). All the evidence we have about gentrification is indirect and anecdotal, and while being touched upon at several appropriate points, does not form a central part of the analysis. Rather, the paper focuses on the demographic side of reurbanization, and its links with possible processes of gentrification discussed only in the context of specific examples.

When discussing the multiple connections between reurbanization and demographic shifts, it is impossible to omit the influence of social changes linked to the concept of the "Second Demographic Transition" (SDT). Initially coined by Lesthaeghe and van de Kaa (1986) and 
subsequently "loaded" with a variety of additional meanings, explanations and debates (for a review, see Sobotka et al., 2003), the SDT was primarily conceptualized as a decline of fertility "well below replacement", as a result of fundamental behavioural changes, which, according to vanVan de Kaa (1987) included four shifts: i) from the "golden age of marriage" to the "dawn of cohabitation"; ii) from "the king-child with parents" to the "king-pair with a child"; iii) from "preventive contraception" to "self-fulfilling conception"; and iv) "towards pluralistic families and households" (p. 11). As such, the SDT has come to encapsulate a set of developments that are directly linked to the "atomization" and "individualization" of society, as a result of the rise of the "reflexive self," the emergence of a "society of friendship," and the growing importance of "weak ties" (e.g. Watters, 2003; Giddens, 2001; Verdon, 1998 and Granovetter, 1973 for further elaboration, but also Cliquet, 1991 for a critique of the SDT).

In their entirety, processes associated with the SDT have led to further declines in fertility rates, the postponement of childbirth, a rising number of extramarital births, later and less marriage, higher divorce and cohabitation rates, as well as the emergence of non-traditional living arrangements, such as "living-apart-together," flat-sharers, and step-families (Frey and Kobrin, 1982). It has been claimed that the productive requirements, consumptive desires and personal contacts of these household structures are re-weaving the metropolitan tissue, thus leading to new patterns of urban settlement, movement and growth (e.g. Fishman, 2000; Buzar et al., 2007a; 2007b). However, in light of the complexity of urban social change related to the SDT, the inherently controversial nature of the concept, as well as limitations on paper length and the availability of data, the analyses in the sections that follow focus on two specific aspects of the process:

- Fertility and ageing trends across the city;

- The presence of SDT-related household types (one-person households, flat-sharers, cohabiting couples) in the inner city, and their migration into such areas.

However, considering that both the progress and characteristics of the SDT and demographyrelated urban change in Spain have been grounded in the specific cultural, legal and institutional circumstances of the country and its constituent region, the following part of the paper provides a brief overview of some of the key relevant developments at the national level.

\section{RECENT URBAN, SOCIAL AND ECONOMIC TRENDS IN SPAIN}

Although Western Europe underwent far-reaching economic transformations during the nineteenth century, Spain faced major difficulties in modernizing its society and economy until well into the twentieth century. Up until the Second World War, Spain's social and economic development lagged far behind the levels attained by the more industrialized countries of Western Europe (Sánchez-Albornoz, 1985). However, the 1950s saw the advent of rapid economic growth that intensified further during the 1960s and the early 1970s (a period also known as desarollismo, see Sánchez Zurro 1989). This was followed by a second cycle of economic expansion during the mid-1980s, which propelled Spain into the company of Western Europe's more advanced industrial societies (Méndez and Molinero, 1993). 
But industrialization led to growing regional disparities between, broadly speaking, prosperous coastal regions and less-developed inland areas. Economic development and population growth in Spain has been disproportionately concentrated in several distinct parts of the country, such as the major industrial centres in Barcelona and surrounding Catalonia, the northern region of Asturias, the Basque province, Madrid, and to a lesser extent, the mineral-rich southwest (Pareja-Alonso, 2000; Dura-Guimera, 2003). In contrast, the country's less-developed provinces follow a vast arc separating Madrid from the northern coast and Catalonia.

Spain's most pressing economic problem over the last thirty years has been the persistence of high unemployment. The industrial changes brought about by post-Fordist economic change, declining job opportunities in agriculture, and falling demand for Spanish workers in Western Europe, kept unemployment rates above 20 per cent throughout the 1980s (Regales and Miranda, 1994). Moreover, overall employment between 1976 and 1985 declined by almost 25 per cent, as the sharp slowdown in labour demand following the first oil shock coincided with the growing exodus from rural areas (ibid.). The decline in industrial employment can be attributed to production downsizing in a number of key sectors, as well as previous "overemployment," low productivity and high labour costs (Roura, 1998).

As pointed out by Reher (1998), the "the period from, say, 1875 to 1975 witnessed one of the most profound social, demographic, economic, and political transformations in [Spanih] recorded history" (p. 133).The urbanization of this country's population during the intense processes of industrialization and economic modernization that marked the second half of the twentieth century created a specific pattern of demographic and social development in the country. From a demographic point of view, Reher maintains that by 1975 "the process of modernization was well advanced," laying "most of the foundations ... for the issues and challenges confronting Spanish families today" (ibid.).

The last 30 years have seen dramatic demographic change in Spain (Puyol, 1997). Although Spanish demographers underscore the differences of Spanish socio-demographic development relative to "leading" SDT states in Northern Europe (ibid., p. 142), it is also true that Spain has exhibited a number of SDT-related processes at their most extreme due to the sheer rapidity of societal, political and legal change. For example, although patriarchal traditions are still very strong in some rural areas (Barrera-Gonzales, 1998), Spain's total fertility rate dropped from 2.8 to 1.2 children per woman between 1970 and 2005, thus reaching one of the lowest levels in Europe (Puyol, 1997, p. 101; Council of Europe, 2006). The decrease in fertility to a "lowest low" rate has been accompanied by an increased longevity of the population, and consequently, accelerated demographic ageing dynamics.

Moreover, Spanish women now marry and have children later than many of their European counterparts, so that the mean age of childbearing is now 31, compared with under 25 in 1970 (see Puyol, 1997, p. 123; Council of Europe, 2006). The share of children born out of wedlock is also rising. Although the marriage and divorce rates are, respectively, slightly higher and lower than the European average, here, too, one can observe evidence of the SDT: the divorce rate has more than doubled during the last 20 years. However, population numbers have been maintained by the fact that this country has become a net recipient of immigration from Africa, Asia and Southern America (Puyol, 1997, pp. 220-238). 
The dissolving of traditional family and household structures has combined with the country's specific urban development logic, to affirm the Spanish city as a specific spatial, cultural and demographic form. According to Muñoz (2003), cities in Spain "have been conceived, and they are still considered, as a reservoir of urban diversity because of the archetypal image of density, urban complexity and social diversity" (p. 385). Luna-Garcia (2003) claims that the traditional model of housing in Spain "has proved to be very beneficial in the long run" because some of the areas that were developed "haphazardly in the 1960s and 1970s" are "now very attractive working class neighbourhoods, with all sorts of social and cultural infrastructure and with a considerable quality of life for their residents" (p. 379). This is, to a certain extent, confirmed by the rising concentrations of "non-traditional" household types such as young people living alone, cohabiting couples and unrelated flatsharing young adults during the last 20-30 years (Puyol, 1997).

\section{RECENT DEMOGRAPHIC DEVELOPMENTS WITHIN LEÓN}

Before looking at the nature of recent social, economic and demographic developments it should be pointed out that León's host region - Castile and León - has lagged behind the rest of the country in terms of economic and population growth since the mid nineteenth century (Ballesteros and Pozo, 1995; Fuente, 1998; Meyer, 2001). Even though it was never densely populated, the region has experienced constant migration loss over recent decades. While this outflow was more than compensated for by the natural increase of the population in the immediate post-war period, the last 30 years have seen an overall demographic decline accompanied by population ageing, due to falling birth rates and the out-migration of younger age groups (Meyer, 2001, p. 27). However, the future demographic prospects of the Castile and León may be aided by the recent upturn of economic growth, which exceeded the national average in 2006 (Eurostat, 2006; Meyer, 2001, p. 29).

León itself plays an important role in the regional economy. Even though this city's growth in the 1960s was initially fuelled by industry, its economy is now largely service-based, with 57 per cent of GDP being generated by the tertiary sector. Still, at 35 per cent of GDP, industrial activity is also an important source of revenue and employment. Construction is a key industrial branch, providing nine per cent of total GDP (INE, 2007). But the role of the secondary sector in generating jobs has diminished in the last quarter of the twentieth century due to labour outsourcing. The unemployment rate has been kept below ten per cent only as a result of the growth of service jobs, where the total number of employees increased from 56,000 in 1960 to 94,900 in 1998. Public organizations are the single largest generator of wealth in this sector, since they account for 30 per cent of its total contribution to local GDP (ibid.). Tourism is a key asset of the city's economy, thanks to its central position on the "Heritage trail" to Santiago de Compostela, which attracts tens of thousands visitors every year (Meyer, 2001, p. 36). Thus, hotel services and retail make up almost 40 per cent of the service sector (INE, 2007).

Statistical data about the nature of population trends within the administrative boundaries of the León urban area are generally disaggregated at the level of two large units: León "proper" (which comprises the contiguous built-up area of the city around its mediaeval core, including collective and individual housing constructed mainly during the twentieth century), 
and the "outskirts" of León, which consist of the surrounding suburban and ex-urban settlements that do not form a continuous whole with the rest of the city but are functionally closely connected to it. León "proper", the focus of this paper, is further subdivided into ten statistical districts, nine of which are dominated by residential and commercial uses.

León underwent a rapid expansion of its population during the twentieth century, thanks to high levels of rural-to-urban migration. Population growth was mainly concentrated in the core city: although León proper had a little more than 15,000 people in 1900, this number now stands at almost 140,000. As shown by Figure 2, the total population of this part of the city began to fall only in the mid-1990s, having recorded constant increases throughout the twentieth century. However, the relative rate of population growth has been declining since 1970. Although the slowing down of population growth rates during the 1940s and 1950s can be attributed to broader economic and political problems experienced by Spanish society during these decades, it is likely that the post-1970s fall is largely due to suburbanization. However, it should be pointed out that the total number of households has been increasing since 1991: from 45,426 in 1991 to 53,232 in 1996 and 55,608 in 2004 (e.g. Buzar et al., 2007a). This points to an underlying reduction in household size - a common trend in Spain during the same period (Puyol, 1997).

[insert Figure 2 about here]

The demographic decline of León proper (where the number of inhabitants decreased from 145,242 in 1996 to 136,985 in 2006, according to INE, 2007) has contradicted population trends in other parts of the city. This is because the outskirts of León have constantly gained population since 1960: their population grew from 32,396 to 46,046 between 1996 and 2006 (INE, 2007). The growth of exurban settlements has offset the population decrease experienced by the rest of the city during the late 1990s, helping to keep the total number of residents at, more or less, a constant level. Moreover, post-1960s population developments within the León urban area stand in contrast to the unfavourable demographic situation of its host province and region, whose total population has decreased by more than 20 percentage points during the same period. The growing gap between population trends in the León urban area - and especially its outskirts - on the one hand, and its host province and region, on the other, epitomizes the gravitational pull of the city on the population of this part of Spain.

Nevertheless, even though the population of León has been relatively stable, there is a persistent trend of ageing throughout the city. This is especially pronounced in León proper, which has a significantly older age structure than the outskirts, and is ageing more quickly: the proportions of younger and older age groups in this area have been, respectively, decreasing and increasing at a faster pace compared to the outskirts. Thus, while in 1981 the youth rates $^{2}$ for León proper and the outskirts were relatively similar at, respectively, 25.8 per cent and 24.6 per cent, they decreased to 17.2 per cent and 20.9 per cent in 2001 . But elderly rates increased during the same period, especially in León proper - from 11.5 per cent to 20.9 per cent (the outskirts registered a rise from an elderly rate of 10.7 per cent to 15.6 per cent). The dependency ratios ${ }^{3}$ of the two areas are still relatively similar, though $-6.2: 1$ in León proper and 5.8:1 in the outskirts - owing to the presence of a large middle-age cohort in both the city centre and the districts around it. 
The ageing of the population is clearly seen in the crude birth and death rates of León proper and the outskirts, as well as the resulting natural balances for both areas. Although the crude birth rate of León proper was significantly higher than that of the outskirts in 1985 - at 11.9 per thousand vs. 8.6 per thousand -it is now less than 8 per thousand, and has barely recovered from the 6.3 minimum reached in 1994 (the crude birth rate for the outskirts has remained relatively constant at around 8.5 per thousand). But crude death rates have been rising in León proper since the late 1980s, due to its older age structure: they have increased by approximately 15 per cent, to exceed 9.5 per thousand). As a result, León proper has registered a negative natural balance throughout the 1990s, while the opposite has been true for the outskirts, where the age structure is more progressive (see Figure 3).

[insert Figure 3 about here]

In-migration has compensated for the net natural decline and has played a crucial role in maintaining the demographic vitality of the city. The León urban area has registered a positive migration balance throughout the $1990 \mathrm{~s}$, though, once again, it is the outskirts that have gained population at the expense of León proper. This is mainly due to lower rates of out-migration from the former (see Figure 4). Such trends could suggest that, similar to broader developments in Spain, better-off households are concentrating at the urban fringe as a result of the shift of residential preferences towards single family housing, thus blurring the spatial boundary between the outskirts of the city and its rural hinterland (Meyer, 2001, p. 208). It is indicative that the people who decide to move to the outskirts mostly come from the rest of León province, while those from outside the province overwhelmingly prefer the contiguous urban area of León. But, equally, the latter is over-represented in the structure of extra-provincial out-migration (see Figure 5).

[insert Figures 4 and 5 about here]

One of the reasons why so much population growth has occurred in the outskirts may be due to the better quality, size and availability of housing. In general, dwellings in the outskirts tend to be bigger (for example, there are almost twice as many apartments larger than $120 \mathrm{~m}^{2}$ in the outskirts compared to León proper) and newer (more than half of all dwellings in the outskirts have been built during the last 20 years, while the equivalent figure for the contiguous urban area is less than 20 per cent). Over the last 15 years, the outskirts have seen the highest rate of new private housing (20 per cent more than León proper), which also represents the majority of new housing in the León urban area. However, the rate of new housing construction in the outskirts is gradually lagging behind the growth of population in this part of the city. This is indicated by the ratio of new housing to new households in the area: it has been decreasing since 1999, and dropped below one in 2002.

The spatial distribution of households and international migrants in the León urban area does not necessarily conform to the broader patterns of natural change and migration in the city. Average household size increases rapidly as one moves from the centre to the suburbs. In the centre of León (including Districts 1, 2 and 5) this figure is significantly lower than the citywide mean, while outlying districts such as 8 and 6 have average household sizes similar to the outskirts (Figure 6). One-person households have a similar spatial distribution: they are particularly over-represented in District 1 - a densely built-up area with multi-storey, 
tenement block housing from the first half of the twentieth century. The lowest concentrations of one-person households may be found in the residential quarters surrounding the centre, including Districts 3, 6, 7 and 8 (see Figure 7). International migrants, who do not play a significant role in the residential population of León, have tended to concentrate in low-rent working class areas outside the inner city. In their entirety, such processes indicate that, in addition to suburbanization, other kinds of dynamics are also at play in transforming the urban demographic landscape.

[insert Figures 6 and 7 about here]

Not only do the outskirts have a younger population with a positive ratio of fertility and mortality, but they have also been gaining population through net migration. Still, León proper is the final destination of most in-migrants into the León urban area, which means that the negative migration balance is actually due to higher out-migration from it. This area lost nearly 17,000 people through out-migration during the $1990 \mathrm{~s}$.

\section{CASE STUDIES IN THE INNER CITY: CASCO ANTIGUO AND EL EJIDO}

\section{KEY FEATURES OF THE TWO AREAS}

Although meso-level census data can provide a useful "snapshot" of general population trends in the city, their analytical relevance decreases at smaller scales. This is why the research project that led to the publication of this paper also included questionnaire surveys within two inner-city districts of León, which allowed a more detailed examination of their socio-demographic structure and residential perceptions. A total of 467 households were interviewed in the two areas, which corresponds with a response rate of 72 per cent of all contacted households (Haase et al., 2005, p. 30). The high response rate was achieved thanks to a careful preparation of the questionnaire itself, a detailed coaching of the interviewers as well as the active participation of the whole research team in the survey activities (for a further discussion of the methodology, see Steinführer et al. 2008). Questions asked dealt with the living arrangements of the interviewed households, their housing biographies, needs, and preferences, as well as attitudes towards the residential environment.

Before looking at some of the results of the survey, however, it is worth outlining the spatial and demographic features of the two case study areas. The first of these - Casco Antiguo comprises the historical city centre of León, which includes the main complex of its mediaeval architecture, as well as key areas of tourist interest. As such, the area has a mixed function, with residential and commercial uses heavily intertwined. During recent decades, it has been suffering from a population decline caused by ageing and net out-migration, in addition to shrinking shopping facilities and increased spatial conflicts between residents, on the one hand, and nightlife and tourists on the other, especially in the so-called "wet quarter" (Barrio Húmedo) which houses a disproportionately high concentration of bars, restaurants and nightclubs (Plate 1). We also observed that - and this was confirmed by some of our interviewees - the residential character of the area has been changing as a result of possible gentrification dynamics entailing the construction of new, upmarket apartment housing (Plate 2 ), though this finding could not be verified through the quantitative data that we gathered. Considering that the age structure of Casco Antiguo is considerably more regressive than 
other inner-city areas and outer districts, it comes as little surprise that the city authorities have been trying to attract new residents to this district, and to adapt its present housing stock to the needs and wants of potential in-migrants (Ayuntamiento de León, 2000, pp. 18-20; Fernández, 2007).

[add Plates 1 and 2 about here]

The second area chosen for case study work was El Ejido, a residential quarter consisting mainly of terraced family houses with small back gardens dating from the 1950s and 1960s. Although it is unusual to find such types of dwellings so close to the city centre elsewhere in Spain, El Ejido has also experienced accelerated ageing processes and population losses during recent years. This is mainly because many of its first-time residents are now approaching pensionable age. Moreover, El Ejido also exhibits a distinct lack of one-person households: their share in the parts of districts 5 and 10 that are within El Ejido is less than 20 per cent of all households, although the overall respective figures in the two districts are above the 30 per cent mark. The proportion of one-person households has not increased significantly between 1996 and 2004, and even the rise that has occurred is probably due to the ageing of the population rather than in-migration, as evidenced by the nearly 5:1 ratio of over-to-under $65 \mathrm{~s}$ in the total population of such households.

However, it is interesting to note that the age structure of one person households in Casco Antiguo is much younger than El Ejido, since the 65+ to 65- ratio in the former is nearly 1:1. Moreover, the proportions of one-person households in the parts of districts 1, 4 and 5 that lie within Casco Antiguo are 30 per cent, 21 per cent and 31 per cent respectively. These numbers have increased dramatically since 1996, and especially in the Barrio Húmedo, where they have nearly doubled. As for the presence of international migrants, the two case study areas once again stand out from the social milieu of the inner city. This is especially true in the southern part of Casco Antiguo, near the Barrio Húmedo, where the share of migrants within the total resident population exceeds the 3.5 per cent mark, against a city-wide average of 2.8 per cent. The relevant figure in El Ejido is 2.9 per cent.

Generally speaking, it can be stated that the two districts do not entirely conform to the general picture of demographic development in the León urban area. Although they are experiencing ageing and out-migration, there is also a visible influx of different types of households and residential groups. These processes are especially pronounced in the southern part of Casco Antiguo, where it is possible to observe a broad trend towards single-person occupancy against possible dynamics of residential gentrification through new-build residential infill in the present housing stock. Conversely, El Ejido retains a distinctive, family-orientated population structure.

\section{SOCIO-DEMOGRAPHIC TRENDS DETECTED BY THE QUESTIONNAIRE SURVEY}

The questionnaire survey provided further insights into the population structure of the two case study areas. For example, the majority of interviewed households had lived in Casco Antiguo and El Ejido for a long time: 61 per cent of all respondents had moved to El Ejido more than 25 years ago, as opposed to 42 per cent in Casco Antiguo. Moreover, the share of interviewees who had lived in their present property for more than 25 years was 56 per cent 
in El Ejido, and 32 per cent in Casco Antiguo. It can thus be deduced that about 20 per cent of the younger interviewees were living with their parents. This finding is congruent with the broader specificities of the housing situation in Spain, where the affordable housing market is constrained by a lack of supply, partly due to high rates of owner-occupancy. It also suggests that there is a remarkably large number of families with adult children and older parents (e.g. also Puyol, 1997; Baizan, 2001).

In-migration trends could be observed at a larger scale only in Casco Antiguo, as 57 per cent of the survey respondents had moved to the area during the last 5 years (see Figure 8). Almost 80 per cent of these "recent" in-migrants consisted of non-traditional households related to the Second Demographic Transition, including childless couples (32 per cent), persons living on their own (19 per cent), and single parents ( 3 per cent). Conversely, the share of recent in-migrants in the El Ejido sample was only 19 per cent, with two thirds being households with children. Young childless households were almost entirely missing from this group of respondents. Nevertheless, the survey indicated that recent in-migration has greatly impacted the age structure of both areas, helping to rejuvenate the inner city of León. This is evidenced by the fact that although residents with a longer housing tenure were older than the city average ( 62 per cent of such respondents in the two case study areas were more than 45 years old, although the equivalent figure for the entire city of León is 42 per cent), recent inmigrants were considerably younger: 89 and 47 per cent of them were, respectively, less than 55 and 35 years of age.

[insert Figure 8 about here]

Cross-comparing the age structures of different household types among the long-standing residential population and recent in-migrants (Figure 9) provides further evidence of the influx of SDT-related households to the inner city:

- The 36-55 cohort was particularly over-represented among survey respondents who had recently moved to the two areas, at 77 per cent of all surveyed households. In contrast, 41 per cent of households within the long-standing resident population were in this age group;

- More than half of the recent in-migrants who were one-person households were less than 36 years of age, while more than 80 per cent of one-person households in the long-standing residential population were older than 55 (though the veracity of this result may be doubted because of the small sample size);

- The heads of almost two thirds of all childless couples who had recently moved to the area were younger than 55 years, as opposed to a mere 8 per cent among the longstanding population;

- The youngest household type among recent in-migrants - even if the sample was rather small - was represented by flat-sharers, as 77 per cent of them were less than 35 years of age. There were no flat-sharers among the long-standing population.

[insert Figure 9 about here]

Moreover, about 48 per cent of recent in-migrants were educated up to university level, while 26 per cent had a secondary education. As for their employment status, the respondents in this group mainly had full or part time jobs (33 per cent), or were students (17 per cent, 
mainly flat-sharing households) and civil servants (16 per cent). The shares of pensioners and unemployed persons were the lowest, at 8 per cent each. It also transpired that the social diversity of in-migrants complements differences in the housing stock, while being reflected in the tenure split. Although El Ejido showed a predominance of home ownership (86 per cent of interviewees), only 61 per cent of respondents in Casco Antiguo were owneroccupiers, with 36 per cent renting their properties (this figure reached 43 per cent among younger households). In Casco Antiguo, there were a number of dwellings with regulated rents, mainly inhabited by older households who have resided there for a longer period of time.

\section{RESIDENTIAL PREFERENCES OF THE LOCAL POPULATION}

The questionnaire survey revealed that the interviewees' residential mobility desires were closely connected to the quality of their dwellings. Some 41 per cent (Casco Antiguo) and 49 per cent (El Ejido) of respondents declared that they intended to move to another dwelling in the near future, but within the same neighbourhood. Hardly any of them wished to relocate to another residential area within León, or the outskirts; the share of households that expressed such a desire was lower than 10 per cent among most demographic groups, except childless couples, where they hovered around the 14 per cent mark. This suggests that both areas are mainly populated by a "city-minded" population, and that the latent mobility towards suburban areas is very low.

That the increased residential attractiveness of inner-city León can be understood in the context of the housing preferences of its dwellers - rather than as a return of suburbanites to the central parts of the city - is further evidenced by the fact that there were no significant differences among the answers of recent in-migrants and the long-standing residents, with respect to the main reasons for their desire to continue living in the two areas (Figure 10). "I feel at home" and "it is peaceful here" were the two most widely-cited responses among both groups, with the only significant differences arising with respect to factors such as proximity to the workplace (where a significantly higher proportion of in-migrants answered positively) and the strength of local social networks (where positive answers were skewed in favour of the long-standing residents). We did, however, note several significant differences in our interviewees' answers with respect to the possible reasons for moving out of the area. While recent in-migrants cited the need to relocate to a larger, owner-occupied dwelling as their leading "push" factor, the top three reasons among the long-standing population were noise pollution, insufficient green space, and the lack of cultural amenities (Figure 11).

[insert Figures 10 and 11 about here]

Interestingly, a significantly lower share of long-standing residents felt that the high cost of living in the area would prompt them to move out of it, although this was one of the top three such considerations among recent in-migrants. It can thus be concluded that indirect displacement is still a weak force in the inner city, despite the anecdotal evidence about gentrification in Casco Antiguo: alongside the visual evidence of gentrification that we encountered in the area (discussed in the previous section), several interviewees pointed out that the renovation of this district's historical building stock during recent decades has prompted better-off family households to buy property and to settle in the area. This might 
suggest that dynamics of "new-build gentrification" (Davidson and Lees, 2005) are taking place in this quarter, but without - as of yet, at least - visible displacement.

In this context, it should be pointed out that noise pollution caused by night clubs concentrated in the Barrio Húmedo was one of the most common concerns expressed by people living in that part of the mediaeval urban core. It was frequently pointed out that the dominant use of the area did not correspond with the needs of older residents that are heavily represented in it. Indeed, the survey results indicated that nearly half of the Casco Antiguo respondents (43 per cent) spent "most of the day in the area/flat," and almost the same percentage (40 per cent) felt "bothered by the constant noise". Such problems had also affected the interviewees' subjective attachment to the area. Thus, 71 per cent of surveyed residents in El Ejido "would recommend the area to a good friend" while the equivalent figure reached only 54 per cent in Casco Antiguo. At the same time, 24 per cent of interviewees in Casco Antiguo gave a negative response to this question, as opposed to 10 per cent in El Ejido.

The survey thus indicated that both areas are developing along specific trajectories, in terms of their residential housing and social structures. Unlike El Ejido - which continues to provide good conditions for family life and bringing up children - Casco Antiguo has, as pointed out by one of our interviewees, turned from a rather abandoned and declining district into a fashionable area for better-off households:

"The level of residents ... honestly speaking, it is a good level, a middle-class area. Middle class, I mean, not upper class but middle ... upper-middle class" (Mr. E, in his 40s, Casco Antiguo)

When asked about the ideal components of a "good home" it transpired that safety, home ownership, and "calm surroundings" played the most important role in both areas. If it is taken into account that a "well-preserved residential environment" was also identified as "important" by many residents, the residential advantages offered by Casco Antiguo in terms of the concentration of newly-built and/or reconstructed middle-class housing in the very city centre, as opposed to El Ejido's possession of inner-city single family housing, become all the more evident.

\section{CONCLUSION}

Going back to the original theoretical motivations and research questions that drove this research, it can be stated that the reviewed evidence indicates that, as a whole, León has experienced a pronounced trend of urban demographic decline over the past two decades. The contiguous built-up area of the city is losing its inhabitants through processes of outmigration and ageing although household numbers are increasing. While the ageing process can be placed in the context of the broader SDT-related drop in fertility rates across the entire country, the population outflows from the inner city have two components: suburbanization (including urban sprawl), and relocation to other parts of Spain. As a result of the former, as well as a continued trickle of rural-to-urban migration, the outskirts of León have continued to gain population both from the inner parts of the city and from other areas of the same 
province. However, this process has been insufficient to offset the demographic decline of the inner city, thus leading to a negative population balance at the level of the entire urban area.

In response to the second question posed in the introduction, it can be concluded that the inner city of León contains small-scale migration patterns that do not entirely conform to the broader-scale picture of demographic decline. The city centre and the areas around it are increasingly beginning to attract "non-traditional" households linked to the SDT: persons living on their own, non-married cohabiting couples, childless couples, and flat-sharers. The newcomers, who tend to have a higher-than-average educational and social status, are taking advantage of the residential amenities offered by the compact nature of the urban fabric. Yet the same areas have also drawn in more traditional households such as extended and multigenerational families, who form a specific social mix with the newcomers and the older residential population. The spatial unevenness of these processes has led different parts of the city to follow different area trajectories. For example, while Casco Antiguo has been attracting more SDT-related households and may be undergoing gentrification and/or studentification dynamics, El Ejido has been rejuvenating its age structure through an influx of more traditional household types, such as nuclear families. Still, both districts have experienced the same general process - far-reaching socio-spatial change with deep impacts on their residential functions.

In their entirety, the observed patterns conform to the broad definition of reurbanization formulated at the outset of the paper. This is because they are taking place against a general context of demographic decline in the city, while involving multifaceted and multidirectional migration flows that are leading to the residentialization of the inner city with a wide variety of socio-demographic groups. In a large part, their driving forces are connected to the dissolution of traditional family patterns and lifestyles, as evidenced by the fact that the inner city is becoming increasingly populated with a wide variety of SDT-related households. Therefore, and in response to the third research question, it can be stated that city-mindedness is an important determinant for residential choice and housing preference among both inmigrants and the existing residential population in inner-city León. Households across different social strata appreciate and value the residential qualities offered by the two surveyed districts, and - except for the adverse effects of noise pollution in the Barrio Húmedo - there is little evidence to suggest that indirect displacement is taking place as a result of the observed (albeit only anecdotally) trends of gentrification in Casco Antiguo.

The reviewed evidence points to several important ways in which the reurbanisation process in a city like León may display specific characteristics stemming from its relatively minor size and position in the Spanish urban hierarchy, as well as the particularities of its broader regional and national context. Most importantly, it is evident that the dynamic of reurbanisation is still "fragile" and constrained by both the broader economic situation of León, and the specific cultures of housing occupancy and residential preferences in Spain. Thus, unlike larger European and Mediterranean cities, the reurbanisation of León's inner city does not include significant numbers of international migrants, being more focussed on SDT-related households instead. This means that the question as to whether the reurbanization process will intensify in the future remains open. Nevertheless, it is clear that areas like Casco Antiguo may potentially undergo significant dynamics of rejuvenation, residential upgrading, and the expansion of gentrification in various forms - including the 
displacement of less affluent residents - if the present processes continue into the future. And, even if such trends are at early stage, they indicate that the perception of the historic inner city as a collection of old, decaying, and dilapidated neighbourhoods - common among the planners and residents interviewed for the purposes of this study - may not be based in fact. 
Figure 1: Location of León within the contiguous part of Spain and its regions.

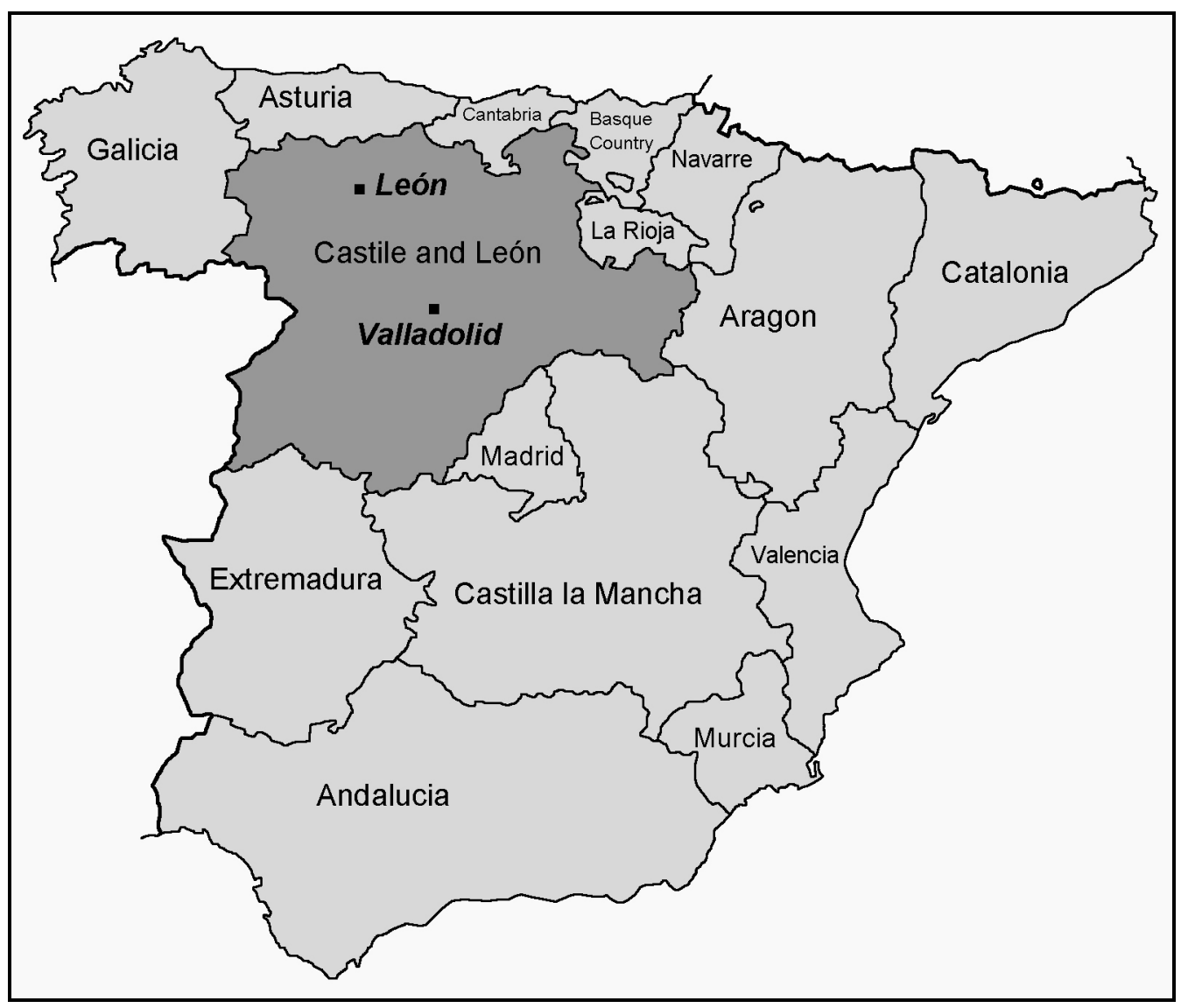


Figure 2: Population growth rates in León between 1900 and 2001 (Source: authors' calculations from statistical data compiled by the City of León).

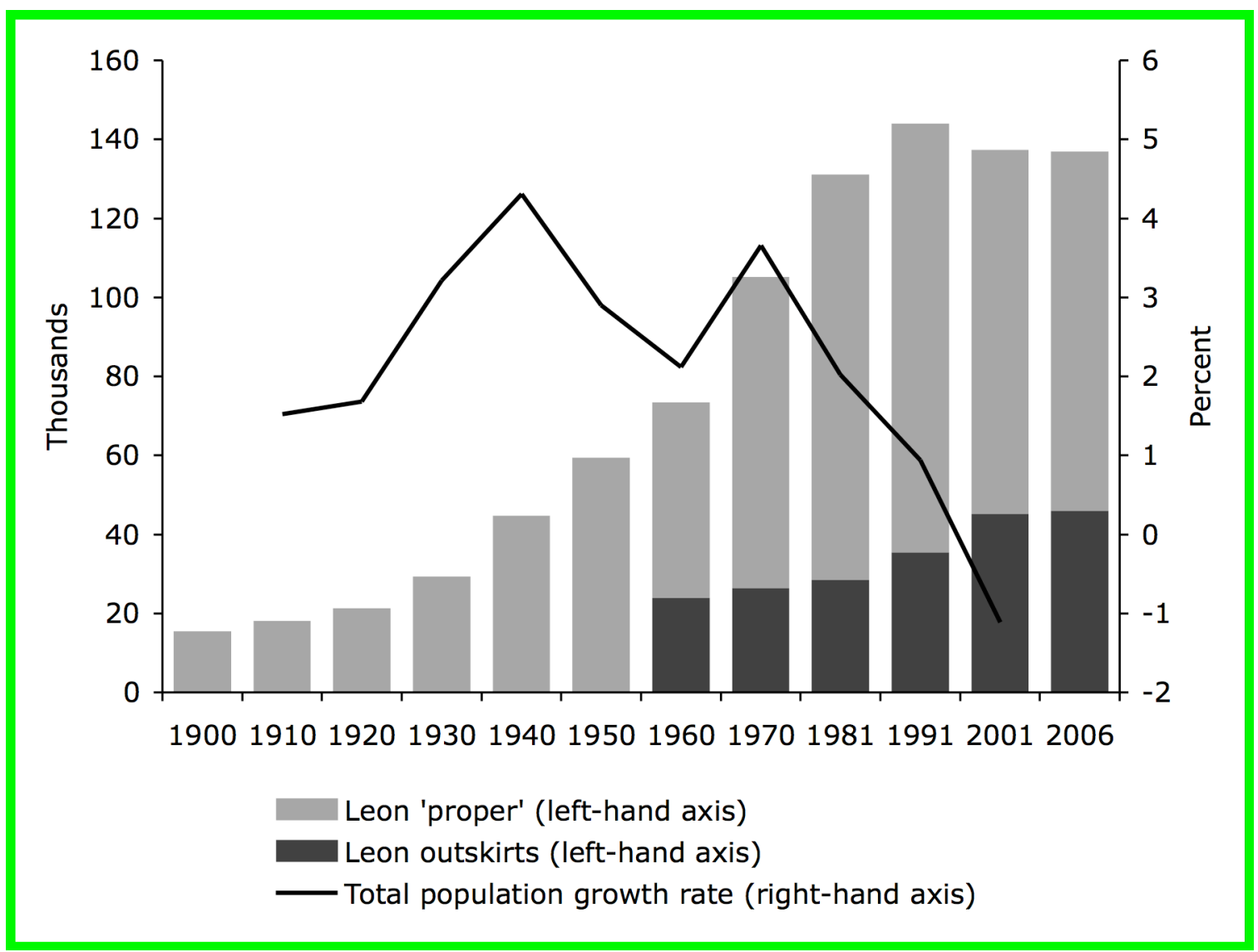


Figure 3: Rates of natural increase (per thousand) in the León urban area, 1985-2000 (Source: authors' calculations from statistical data compiled by the City of León).

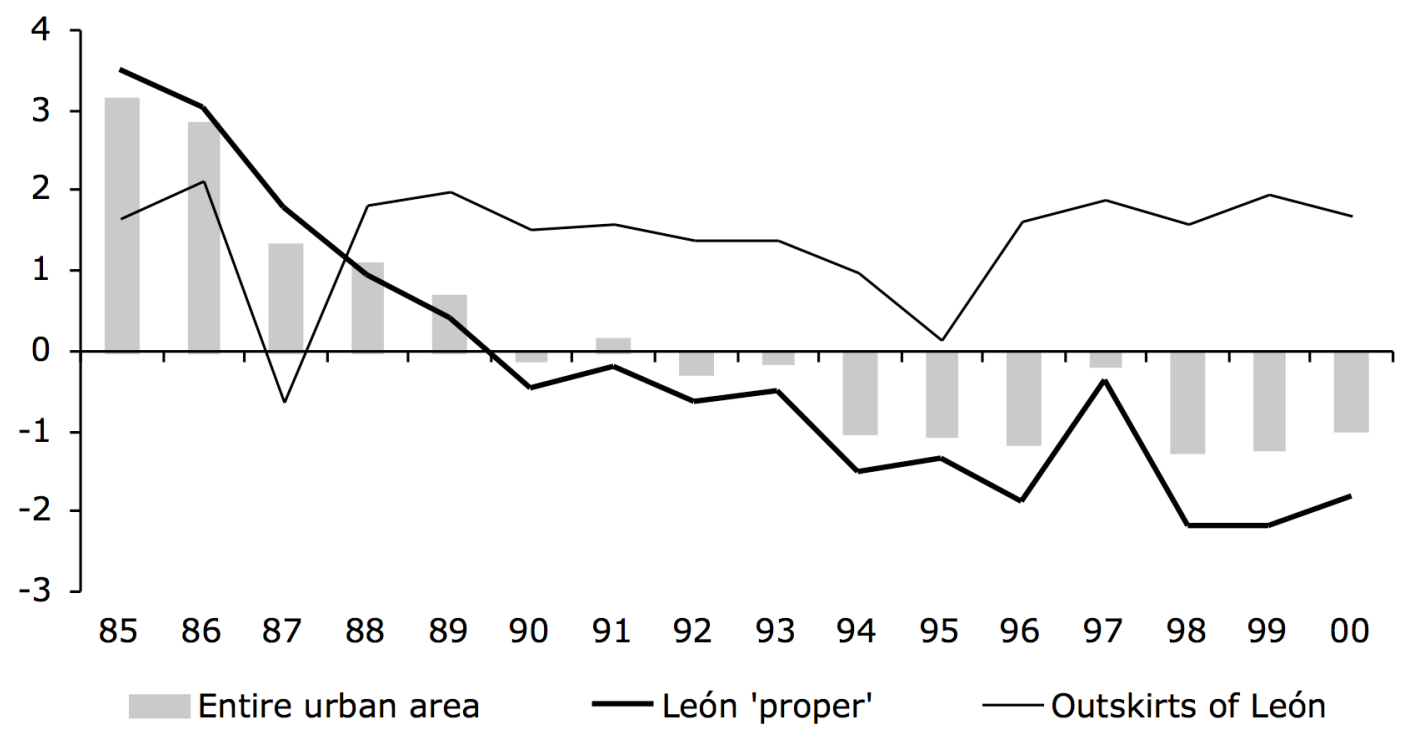


Figure 4: Total number of out- and in-migrants from/to the León urban area, 1990-2001 (Source: authors' calculations from statistical data compiled by the City of León).

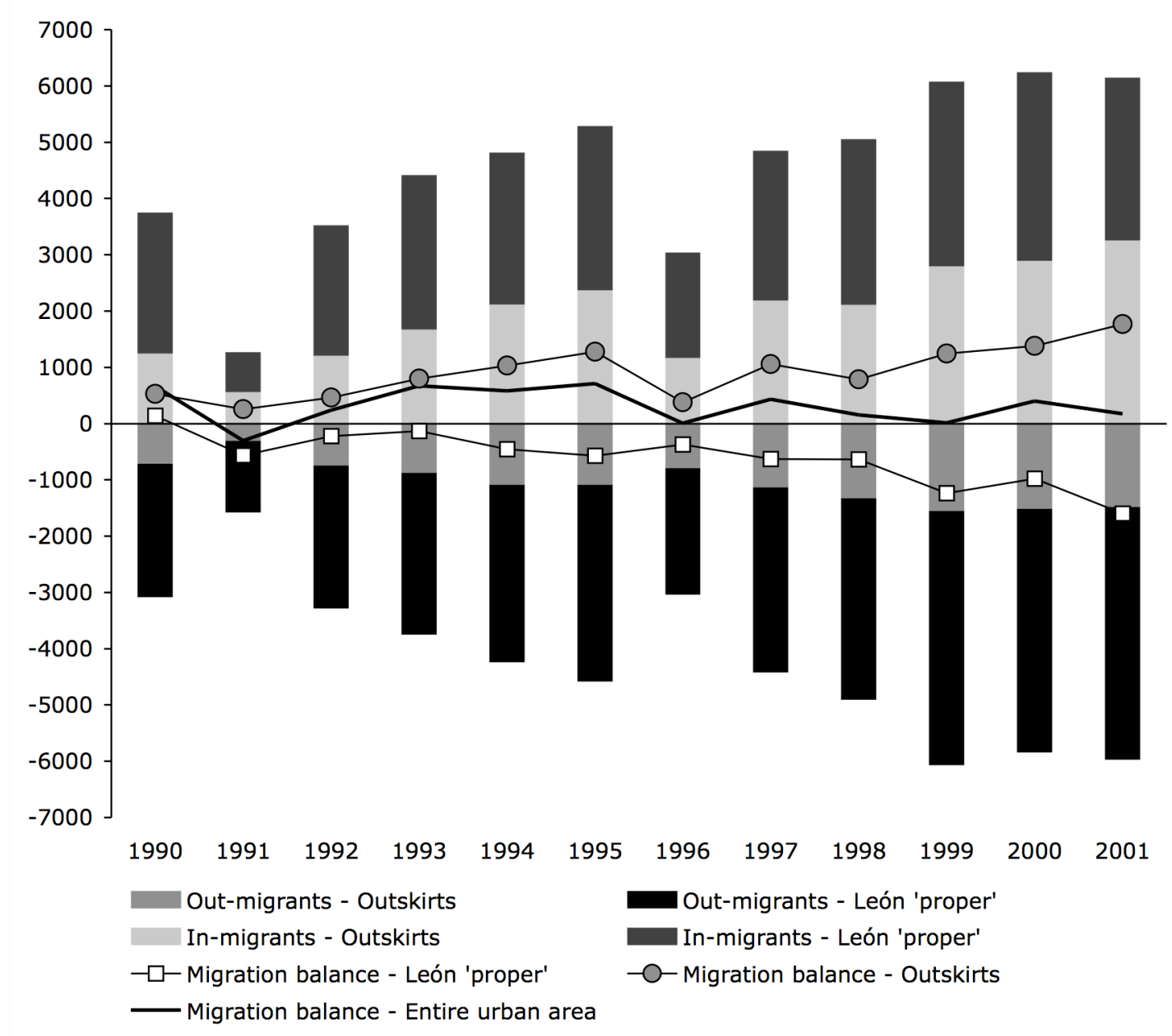


Figure 5: Total number of out- and in-migrants from/to the León urban area, 1990-present (Source: authors' calculations from statistical data compiled by the City of León)

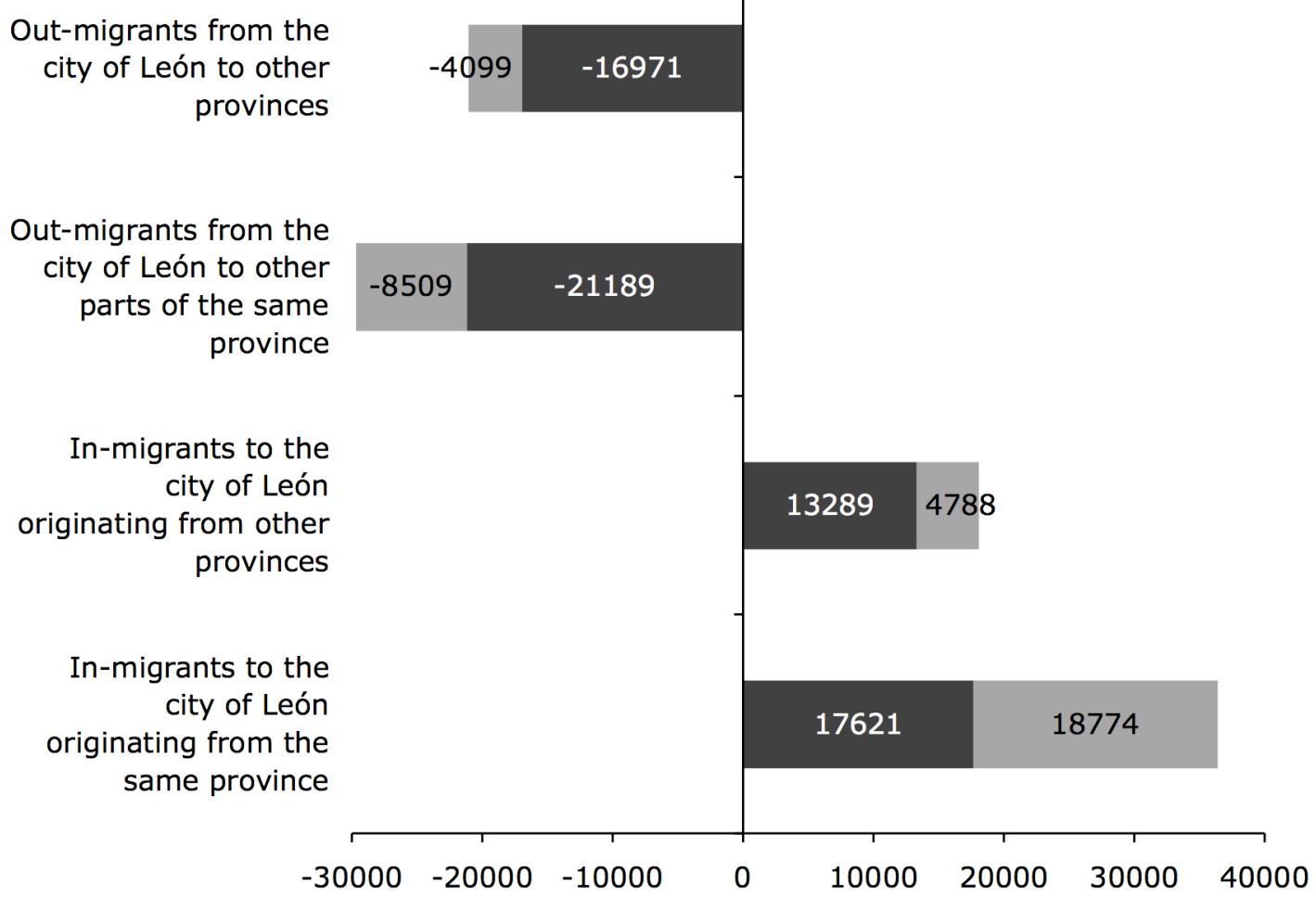

To/from León 'proper'

To/from outskirts of León 
Figure 6: Average household size in different districts of León, relative to the inner-city mean (Source: authors' calculations from statistical data compiled by the City of León). Note: El Casco Antiguo is marked with vertical stripes, while El Ejido is with horizontal stripes. District boundaries have been cropped and generalized to fit map, and District 9 - where there are no residential uses - has been omitted.

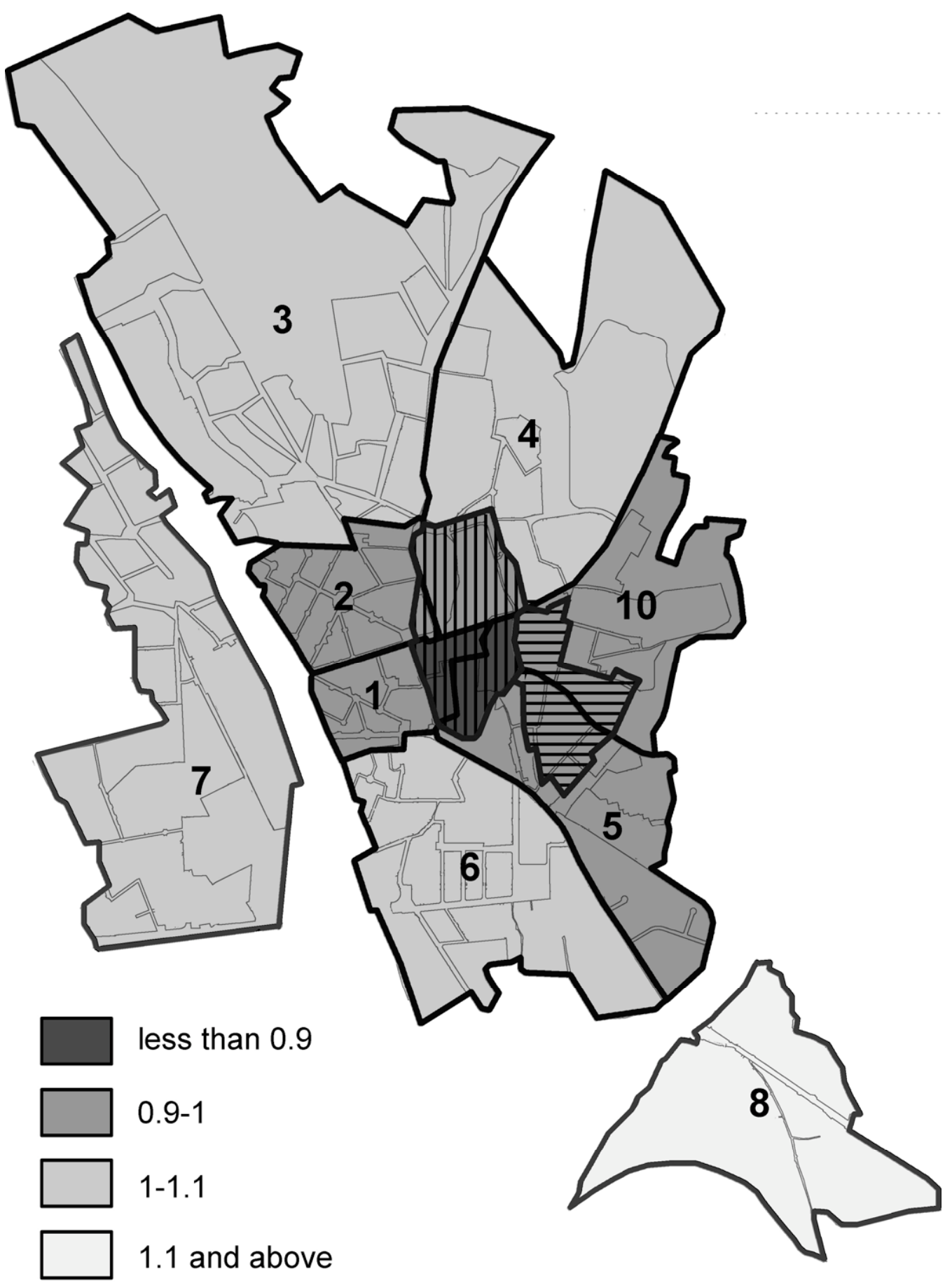


Figure 7: Share of one-person households in different districts of León, relative to the average (Source: authors' calculations from statistical data compiled by the City of León).

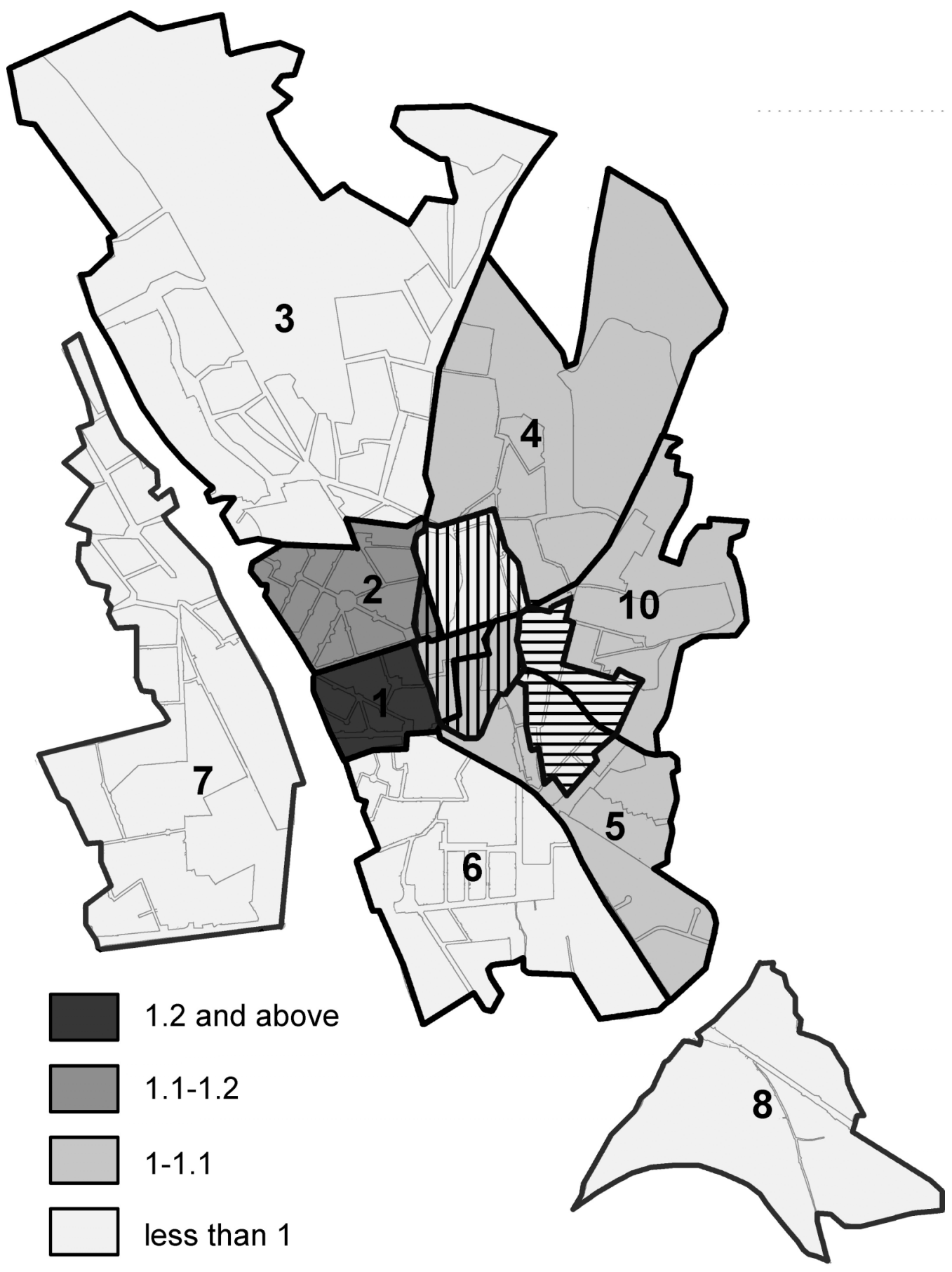


Figure 8: Household structure of recent in-migrants compared to the long-standing population in El Ejido (EE) and Casco Antiguo (CA), based on the outcomes of the questionnaire survey (authors' calculations). Absolute numbers of respondents, where significant, are noted.

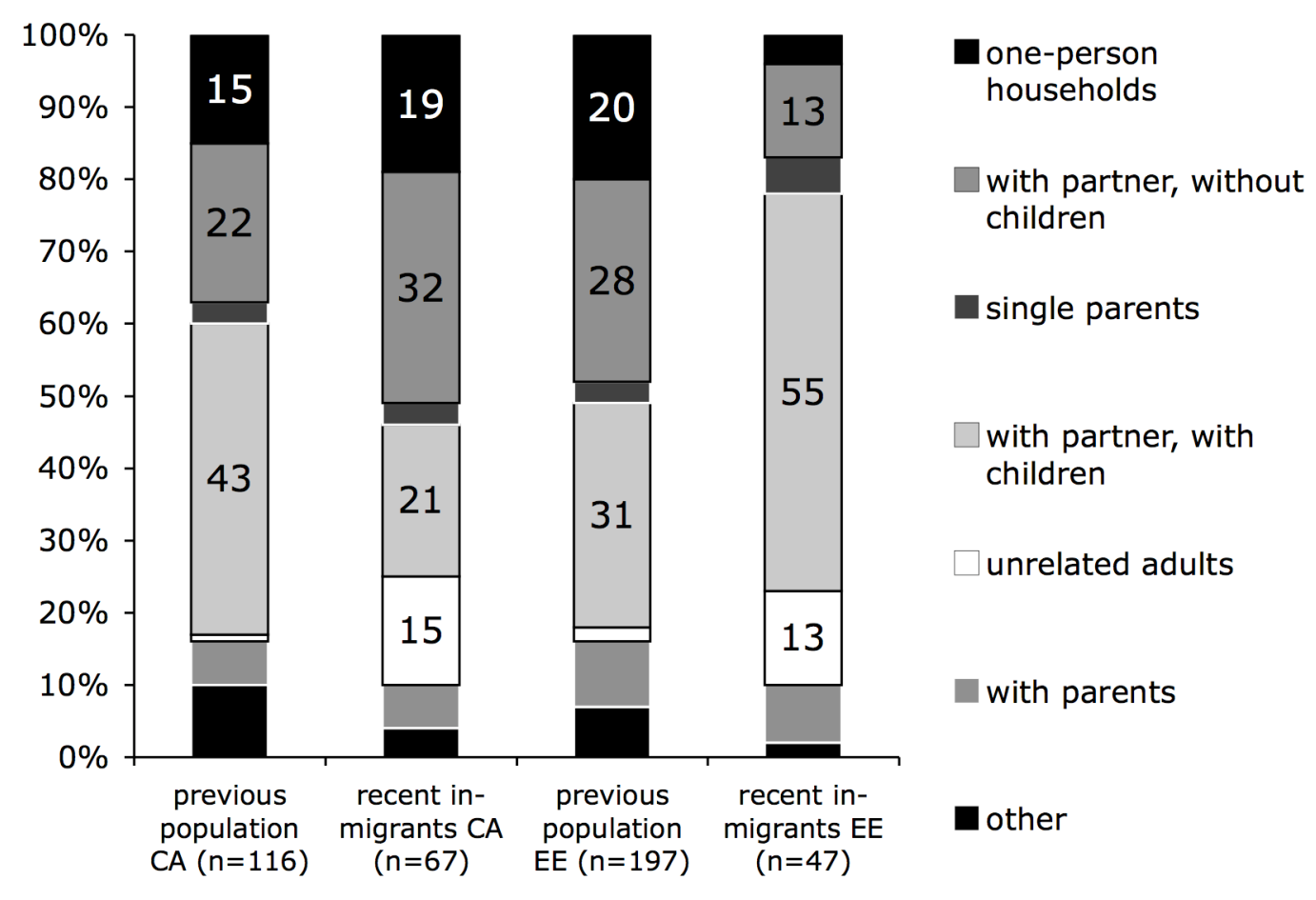


Figure 9: Cumulative age structures of recent in-migrants vs. the long-standing residential population in the two case study areas, based on the outcomes of the questionnaire survey. Absolute numbers of respondents, where significant, are noted.

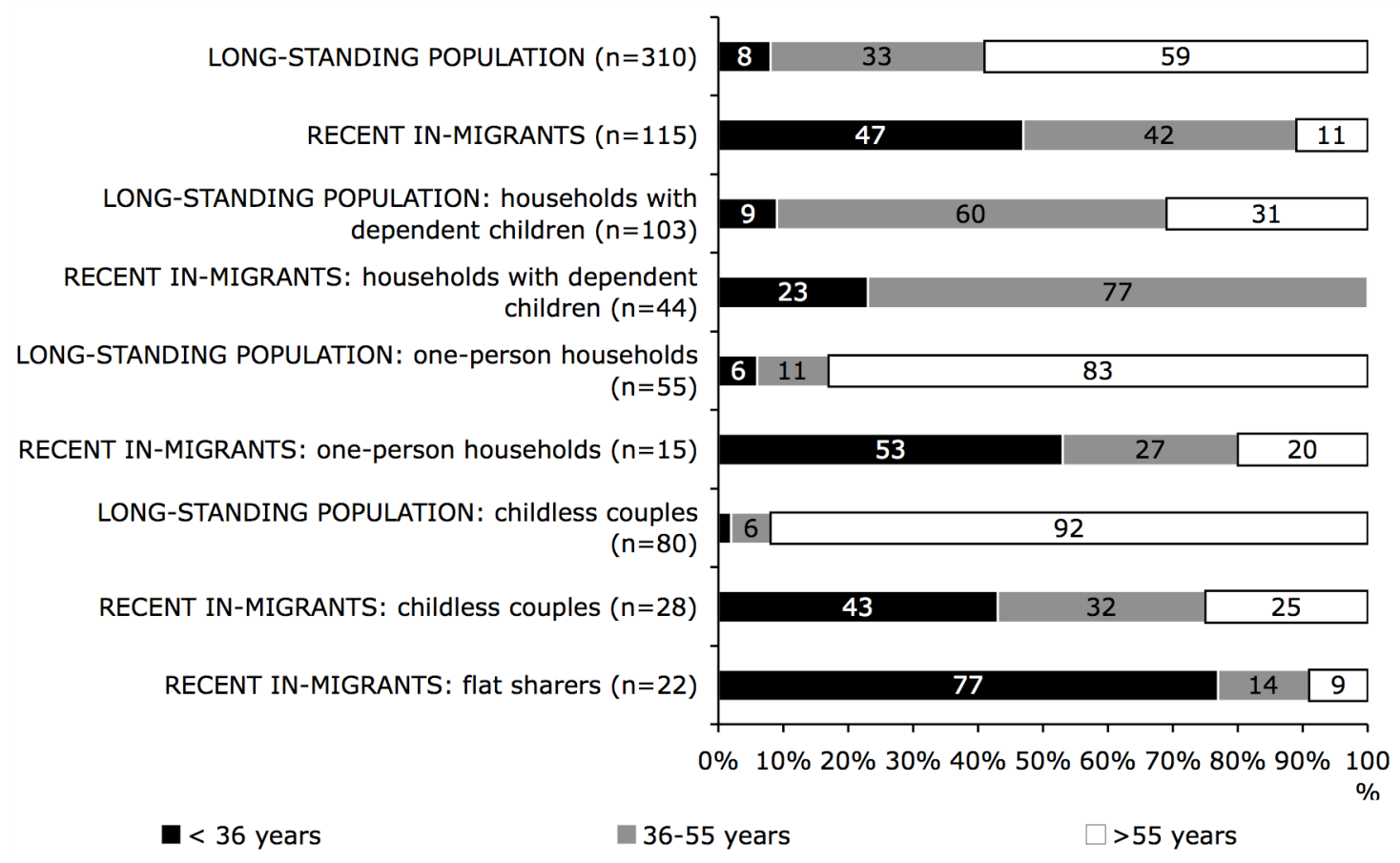


Figure 10: "Reasons to stay" in El Ejido and Casco Antiguo among survey respondents.

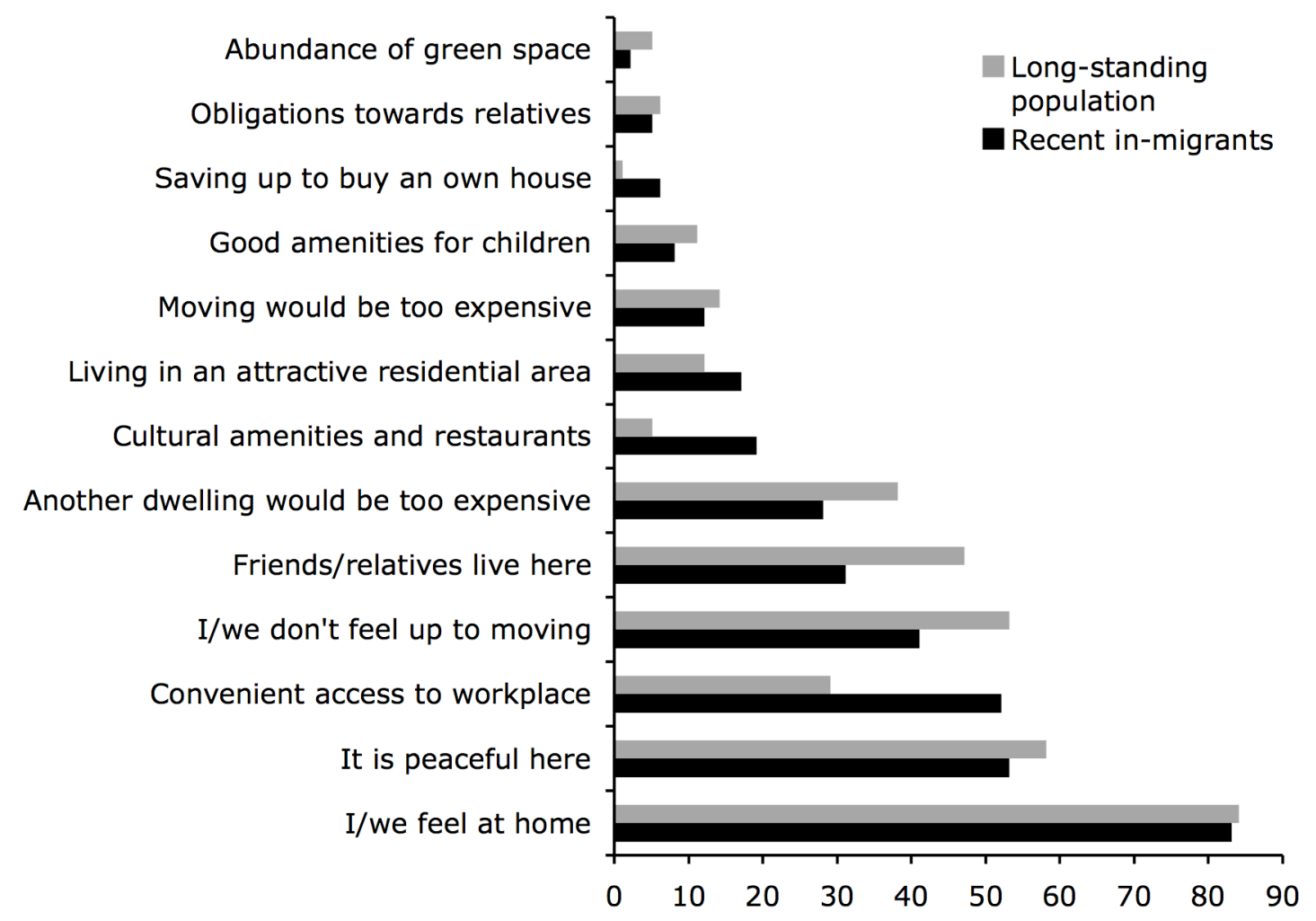


Figure 11: "Reasons to move out" from El Ejido and Casco Antiguo among survey respondents.

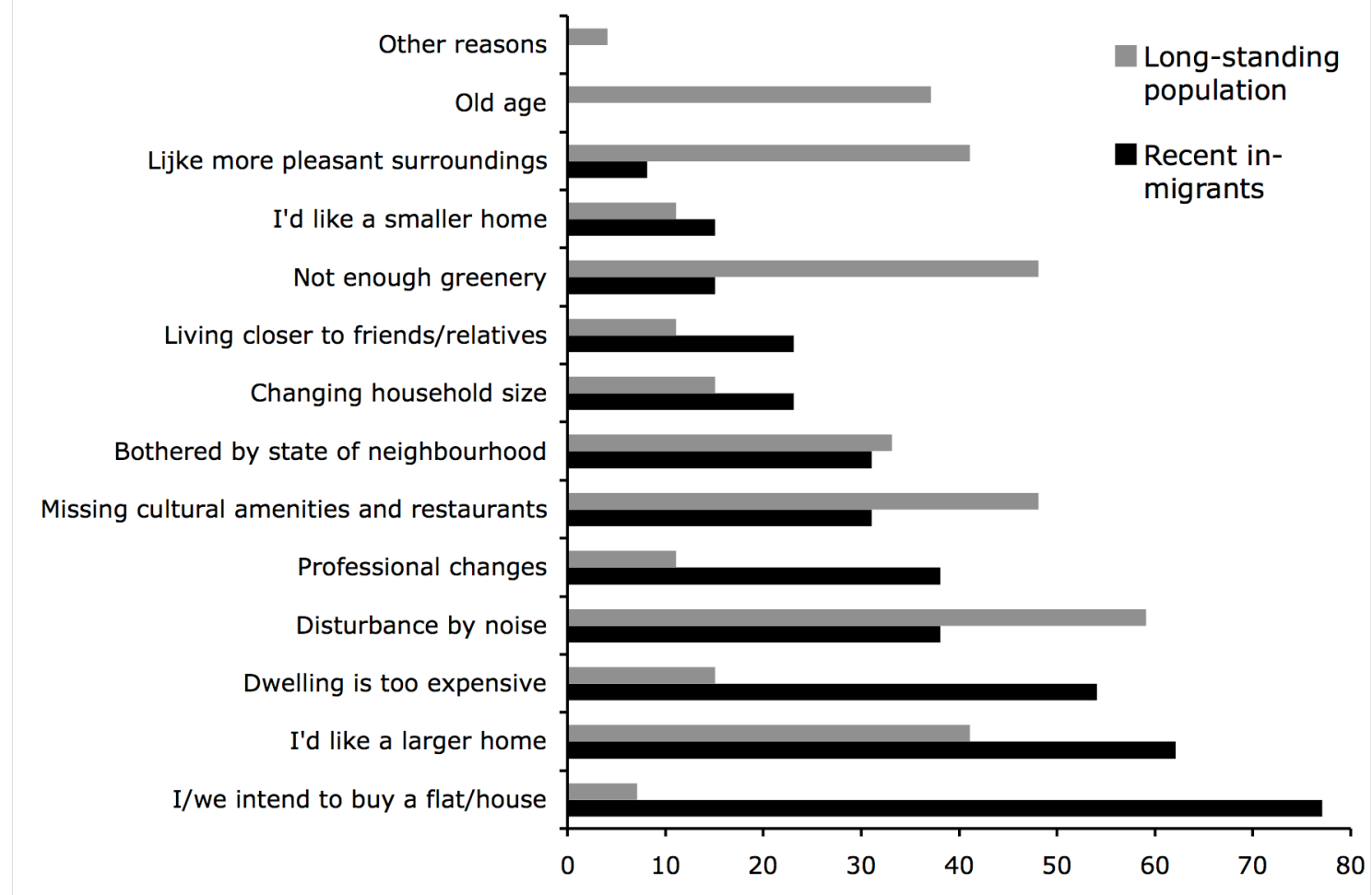


Plate 1: Traditional architecture and modern bars mix in the Barrio Húmedo (courtesy of Re Urban Mobil León team).

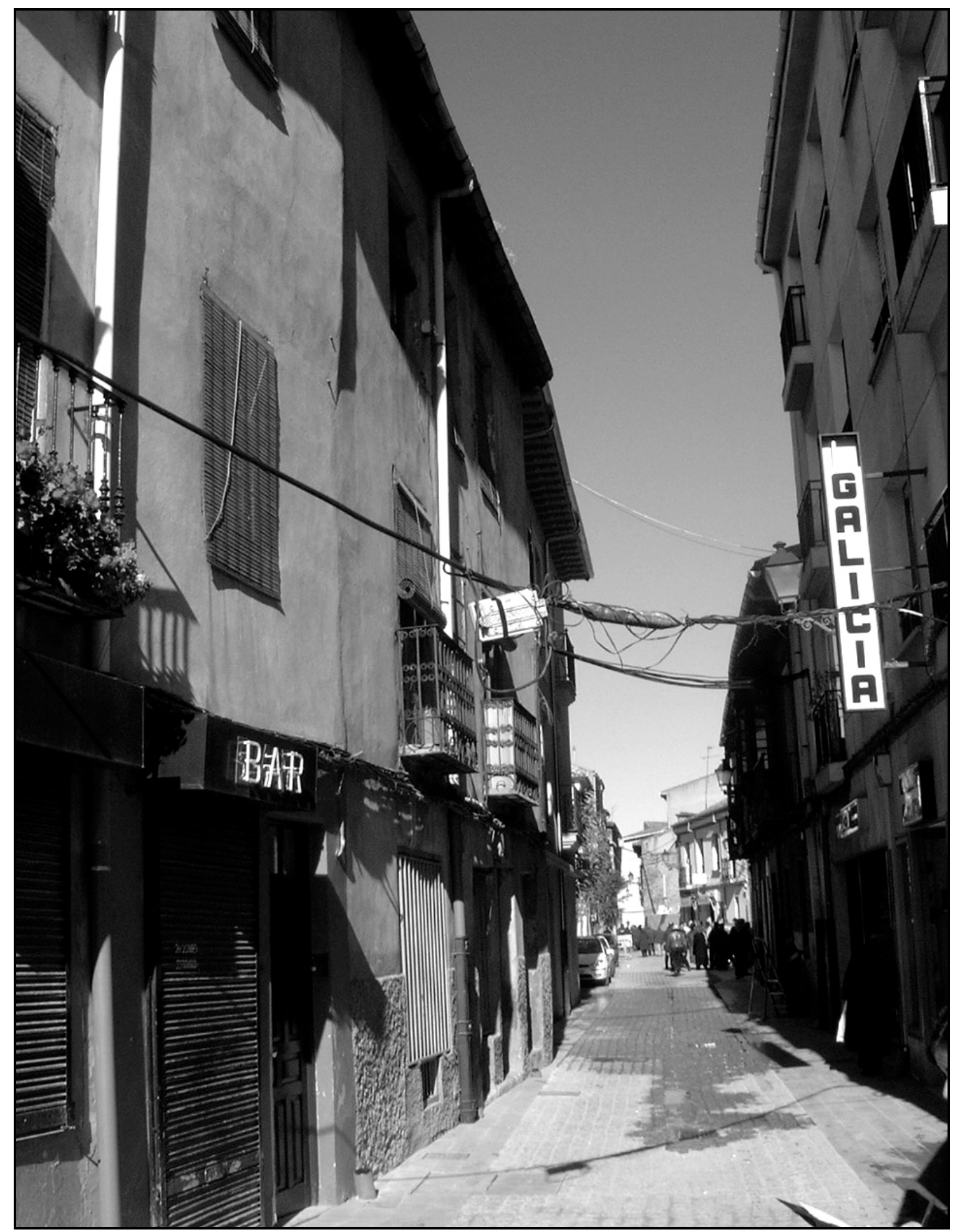


Plate 2: Possible new-build gentrification through residential infill in Casco Antiguo (courtesy of Re Urban Mobil León team).

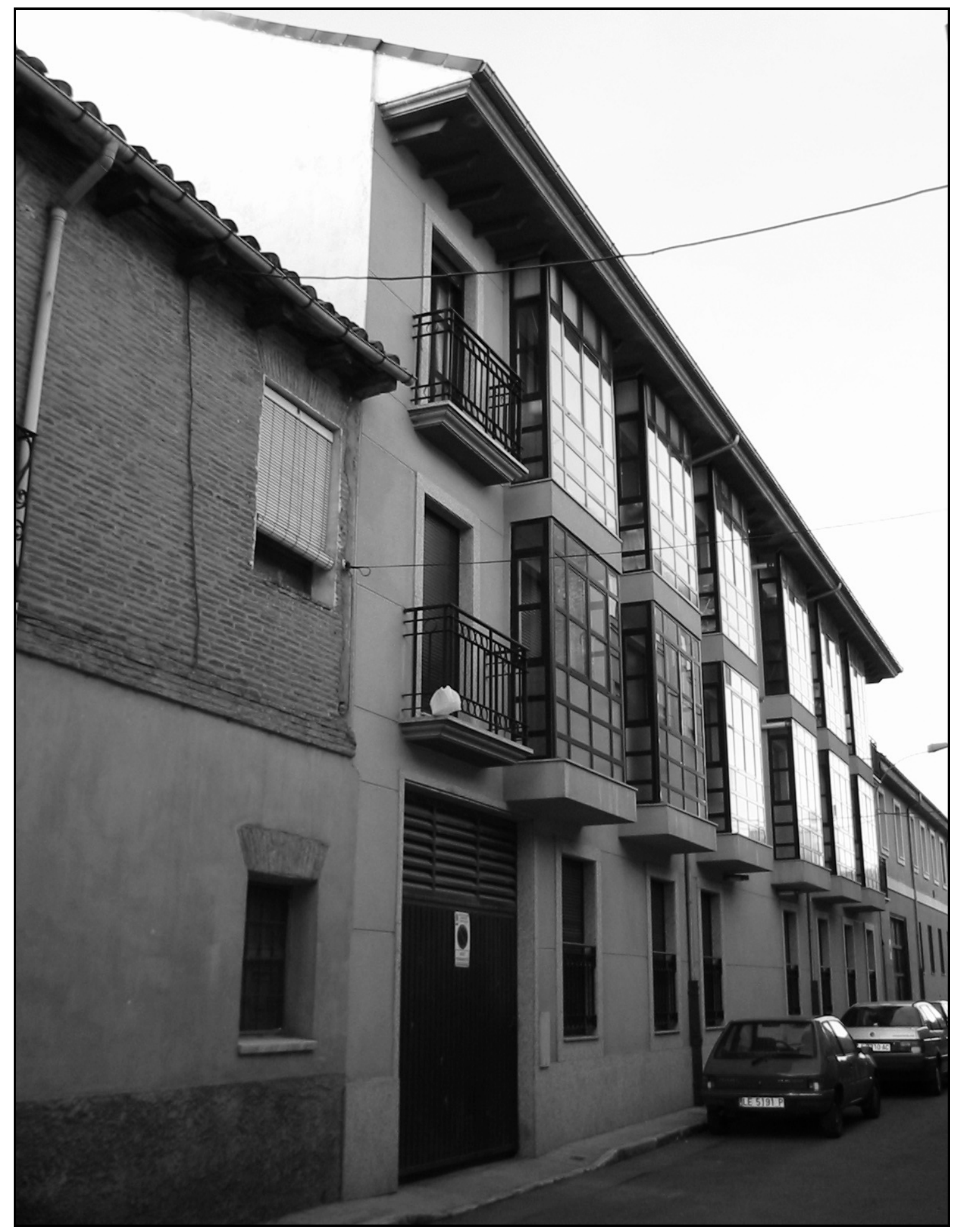




\section{References:}

Ayuntamiento de León, 2000, Plan Piloto Urbano [Pilot Urban Plan]. León: City of León.

Baizan, P., 2001, Transitions to adulthood in Spain. In M. Corijn and E. Klijzing, editors, Transitions to Adulthood in Europe. Dordrecht, Boston, London: Kluwer (European Studies of Population 10), 279-312.

Ballesteros, A. G. and Pozo, E. R., 1995, Los Desequilibrios Socioeconómicos en la España de las Autonomías [Socio-Economic Inequalities in Spain and its Regions].

Barcelona: Masson.

Barrera-Gonzales, A., 1998, Domestic succession, property transmission, and family systems in the agrarian societies of contemporary Spain. The History of the Family, Vol. 3, 221-246.

Bürkner, H.J., 2008, The Demographic Reification Project: Urban Studies under the Impact of Neo-Liberal Naturalism. Paper presented at the conference "Socio-demographic change of European cities and its spatial consequences", Leipzig, 14-16 April 2008.

Burton, E., 2000, The compact city: just or just compact? A preliminary analysis. Urban Studies, Vol. 37, 1969-2001.

Burton, E., 2003, Housing for an urban renaissance: implications for social equity. Housing Studies, Vol. 18, 537-562.

Buzar, S., Hall, R., and Ogden, P. E. O., 2007a, Beyond gentrification: the demographic reurbanization of Bologna. Environment and Planning A, Vol. 39, 64-85.

Buzar, S., Ogden, P. E., Hall, R., Haase, A., Kabisch, S., and Steinführer, A., 2007b, Splintering urban populations: emergent landscapes of reurbanization in four European cities. Urban Studies, Vol. 44, 651-677.

Buzar, S., Ogden, P. E. O., and Hall, R., 2005, Households matter: the quiet demography of urban transformation. Progress in Human Geography, Vol. 29, 413-436.

Cheshire, P., 2006, Resurgent cities, urban myths and policy hubris: what we need to know. Urban Studies, Vol. 43, 1231-1246.

Cliquet, R., 1991, The second demographic transition: fact or fiction? Strasbourg: Council of Europe (Council of Europe Population Studies 23.)

Colomb, C., 2007, Unpacking New Labour's 'Urban Renaissance' agenda: towards a socially sustainable reurbanization of British cities? Planning, Practice \& Research, Vol. 22, $1-24$.

Council of Europe, 2006, Recent Demographic Developments in Europe. Strasbourg.

Davidson, M. and Lees, L., 2005, New build 'gentrification' and London's riverside 
renaissance. Environment and Planning A, Vol. 37, 1165-1190.

Dura-Guimer, A., 2003, Population deconcentration and social restructuring in Barcelona, a European Mediterranean city. Cities, Vol. 20, 381-385.

Eurostat, 2006, General and Regional Statistics. http://epp.eurostat.ec.europa.eu/portal/page?_pageid $=0,1136162,0 \_45572073 \& \_d a d=$ portal\&_schema=PORTAL. Last accessed on 31st April 2007.

Fernández, Ó., 2007, Towards the sustainability of historical centres: a case study of León, Spain. European Urban and Regional Studies, Vol. 14, 181-187.

Fishman, R., 2000, The American metropolis and century's end: past and future influences. Housing Policy Debate, Vol. 11, 199-213.

Frey, W. H. and Kobrin, F. E., 1982, Changing families and changing mobility: their impact on the central city. Demography, Vol. 19, 261-277.

Fuente, A., 1998, What Kind of Regional Convergence? London: Centre for Economic Policy Research.

Giddens, A., 1991, Modernity and Self-Identity: Self and Society in the Late Modern Age. Stanford, CA: Stanford University Press.

Gordon, I., 2004, The resurgent city: what, where, how and for whom? Planning Theory and Practice, Vol. 5, 371-379.

Granovetter, M. S., 1973, The strength of weak ties. American Journal of Sociology, Vol. 78, 1360-1380.

Haase, A., Kabisch, S., and Steinführer, A., 2006, Aufschwung der inneren Stadt in Europa? Reurbanisierung unter den Bedingungen des demographischen Wandels im internationalen Vergleich [A revival of European inner cities? Reurbanization under conditions of demographic change from an international perspective]. Europa Regional, Vol. 14, 167-180.

Haase, A., Kabisch, S., Steinführer, A., Fritzsche, A., Buzar, S., Ogden, P. E., and Hall, R., 2005, Re Urban Mobil Final Research Report. Part B, Sociology. Leipzig: UFZ Centre for Environmental Research Leipzig-Halle, http://www.rerban.com/resources/downloads/outcomes/wp3/WP3partB.pdf. Last accessed on 10th January 2008.

Helbrecht, I., 1996, Die Wiederkehr der Innenstädte. Zur Rolle von Kultur, Kapital und Konsum in der Gentrification [The return of city centers. About the role of culture, capital and consumption in gentrification]. Geographische Zeitschrift, Vol. 84, 1-15.

INE (Instituto Nacional de Estadística), 2007, Data on León. http://www.ine.es/infoine. Last accessed on 4th January 2008. 
Jenks, M., Burton, E., and Williams, K., editors, 1996, The Compact City: A Sustainable Urban Form? London: E\&F Spon.

Karsten, L., 2003, Family gentrifiers: challenging the city as a place simultaneously to build a career and to raise children. Urban Studies, Vol. 40, 2573-2584.

Kohler, H.P.; Billari, F. C., and Ortega, J. A., 2002, The emergence of lowest-low fertility in Europe during the 1990s, Population and Development Review, Vol. 28, 641-680.

Lesthaeghe, R., 1995, The second demographic transition in Western countries: an interpretation. In K. O. Mason and A. M. Jensen, editors, Gender and Family Change in Industrialised Countries. Oxford: Clarendon Press, 17-62.

Lesthaeghe, R. and van de Kaa, D. J., 1986, Twee demografische transities? [Two demographic transitions?]. In D. J. van de Kaa and R. Lesthaeghe, editors, Bevolking: Groei en Krimp [Population: Growth and Decline]. Deventer: Van Longhum Slaterus, 9-24.

Lever, W. F., 1993, Reurbanization: the policy implications. Urban Studies, Vol. 30, 267284.

Luna-Garcia, A., 2003, Cities of Spain, localities on the edge of an identity breakdown. Cities, Vol. 20, 377-379.

Markusen, A. and Schrock, G., 2006, The distinctive city: divergent patterns in growth, hierarchy and specialization. Urban Studies, Vol. 43, 1301-1323.

Méndez, R. and Molinero, F., 1993, Geografía de España [Geography of Spain]. Barcelona: Editorial Ariel.

Meyer, K., 2001, Entwicklung und Struktur der Städte in Castilla y León [Development and Structure of the Cities in Castile and León]. Passau: Selbstverlag des Faches Geographie der Universität.

Muñoz, F., 2003, Lock living: urban sprawl in Mediterranean cities. Cities, Vol. 20, 381-385.

ODPM (Office of the Deputy Prime Minister), 2004, Our Cities are Back: Competitive Cities Make Prosperous Regions and Sustainable Communities. London: ODPM.

Pareja Alonso, A., 2000, The demography of the industrialized province of Biscay in northern spain: spatial differences and long-term changes. The History of the Family, Vol. 5, 431-448

Prytherch, D. L., 2003, Urban planning and a Europe transformed: the landscape politics of scale in Valencia. Cities, Vol. 20, 421-428.

Puyol, R., editor, 1997, Dinámica de la Población en Espana. Cambios Demográficos en el Último Cuarto del Siglo XX [Dynamics of the Population in Spain. Demographic Changes in the Last Quarter of the Twentieth Century]. Madrid: Edición Síntesis. 
Regales, M. F. and Miranda, J. J. C., 1994, Declive Demográfico, Cambio Urbano y Crisis Rural: Las Transformaciones Recientes de la Población de España [Demographic Decline, Urban Change and Rural Crisis: Recent Transformations of the Population of Spain]. Pamplona: Eunsa.

Reher, D., 1998, The history of the family in Spain: past development, present realities, and future challenges. The History of the Family, Vol. 3, 125-136.

Roura, J. R. C., 1998, Convergencia Regional en España: Hechos, Tendencias y Perspectivas [Regional Convergence in Spain: Facts, Trends and Perspectives]. Madrid: Fundación Argentaria.

Sánchez Zurro, D. J., 1989, La Industria Castellano-Leonesa [The Industry in Castille and León]. In Junta de Castilla y León, editor, Castilla y León. Valladolid: Consejería de Cultura y Bienestar Social, 44-61.

Sánchez-Albornoz, N., 1985, La Modernización Económica de España, 1830-1930 [The Economic Modernization of Spain, 1830-1930]. Madrid: Alianza Editorial.

Slater, T., 2006, The eviction of critical perspectives from gentrification research International Journal of Urban and Regional Research, Vol. 30, 737-757.

Slater, T., 2008, A literal necessity to be re-placed: a rejoinder to the gentrification debate. International Journal of Urban and Regional Research, Vol. 32, 212-223.

Smith, D. P. and Butler, T., 2007, Conceptualizing the sociospatial diversity of gentrification: 'to boldly go' into contemporary gentrified spaces, the 'final frontier'? Environment and Planning A, Vol. 39, 2-9.

Smith, D. P. and Holt, L., 2007, Studentification and 'apprentice' gentrifiers within Britain's provincial towns and cities: extending the meaning of gentrification. Environment and Planning A, Vol. 39, 142-161.

Sobotka, T., Zeman, K., and Kantorová, V., 2003, Demographic shifts in the Czech Republic: a second demographic transition view. European Journal of Population, Vol. 19, 249 277.

Steinführer, A., Haase, A., Kabisch, S., 2008, Household-based questionnaire surveys in European cities. Experiences from a cross-national research project. In Grözinger, G., Matiaske, W., and Spieß, C. K., editors, Europe and its Regions. The Usage of European Regionalized Social Science Data. Newcastle: Cambridge Scholars Publishing, 253-270.

Storper, M. and Manville, M., 2006, Behaviour, preferences and cities: urban theory and urban resurgence. Urban Studies, Vol. 43, 1247-1274.

Turok, I. and Mykhnenko, V., 2006, Resurgent European Cities? Glasgow: CPPR Working Paper no. 2. 
Turok, I. and Mykhnenko, V., 2007, The trajectories of European cities. Cities, Vol. 24, 165182.

Van Criekingen, M., 2007, Demographic and social changes in core cities: gentrifying the reurbanization debate, Paper presented at the "New-Build Gentrifications: Forms, Places and Processes" seminar, Neuchatel, 15-16 November 2007.

Van de Kaa, D. J., 1987, Europe's second demographic transition. Population Bulletin, Vol. 42, 1-59.

van den Berg, L., Drewett, R., Klaasen, L., Rossi, A., and Vijberberg, C. H. T., 1982, Urban Europe: A Study of Growth and Decline. Oxford: Pergamon (Urban Europe 1).

Verdon, M., 1998, Rethinking Households: An Atomistic Perspective on European Living Arrangements. London: Routledge.

Vicario, L. and Monje, P. M. M., 2003, Another 'Guggenheim Effect'? The generation of a potentially gentrifiable neighbourhood in Bilbao. Urban Studies, Vol. 40, 2383-2400.

Watters, E., 2003, Urban Tribes: A Generation Redefines Friendship, Family, and Commitment. London and New York: Bloomsbury.

Williams, K., Burton, E., and Jenks, M., editors, 2000, Achieving Sustainable Urban Form. London and New York: Spon Press.

\section{NOTES}

\footnotetext{
${ }^{1}$ Most of this information has been drawn from census data provided by the León City Hall, the Statistics Department of the Government of Castile and León, as well as the National Statistics Institute of Spain. Some of our insights are also based on field interviews with local residents and experts.

${ }^{2}$ The youth rate is the percentage share of under-20 year- $1 \mathrm{ds}$ within the total population, while the elderly rate is the equivalent percentage of over- $65 \mathrm{~s}$.

${ }^{3}$ This can be defined as the ratio between the inactive and active population.
} 